\title{
THREATS AND BENEFITS OF EXCHANGE RATE REGIMES FOR UKRAINE IN TERMS OF EUROPEAN INTEGRATION
}

\author{
Svitlana GLUSHCHENKO' \\ National University of «Kyiv-Mohyla Academy», Ukraine \\ Svitlana TKALENKO \\ Kyiv National Economic University Vadym Hetman, Ukraine
}

\begin{abstract}
The purpose of the paper is to determine threats and benefits of exchange rate regimes in terms of the integration of Ukraine into the European community. Emphasizing features of the manifestation of currency exchange rate in Ukrainian practice is a precondition for choosing the optimal exchange rate regime for Ukraine, which, in its turn, will provide an opportunity to reduce inflation and implement effective tools of monetary and fiscal policies to promote further economic growth and competitiveness of the country. The uses of free-floating exchange rate and «currency board» regimes have either positive effects for Ukraine or certain threats. Methodology. This research is based on a synthesis of data on the uses of exchange rate regimes in Ukraine as an independent. It is considered angular regimes, which are by far the most suitable for Ukraine in terms of the European vector of its development. Peculiarities of using these regimes are revealed and their major threats to the domestic economy are pointed out. This article analyzes the dynamics of the trade balance of payments of Ukraine, the dynamics of the commodity structure of Ukraine's exports and imports and the external debt of Ukraine. Results. Taking into account the experience of countries, which were in crisis situations, they show the necessity of the uses of freefloating exchange rate regime and possibilities of «currency board» regime, despite threats that they may have. World experience testifies the implementation of structural reforms, effective monetary policy, fiscal policy and discipline of the government. Thorough preparation of Ukraine's transition to the «currency board» regime can justify itself in conditions of crisis and provide impetus to Ukrainian economy benefits. The paper defines conditions under which the success of a new model of exchange rate policy will be achieved. Practical implications. The study accents attention on the specifics of the uses of the free-floating exchange rate and «currency board» regimes in the current recessionary economic and political conditions, and the declared Strategy on Sustainable Development «Ukraine-2020» in terms of European integration. Moreover, advantages and threats of the most favorable exchange rate regimes were identified to overcome the economic crisis, and accordingly create conditions for further economic growth and increase competitiveness of the country. This article provides an opportunity to identify the conditions for success of a new model of exchange rate policy to achieve economic stabilization and the beginning of economic growth. Value/originality. Despite the existing studies in the field of exchange regulation at present, there are no comprehensive concepts and a common approach to the uses of an exchange rate regime in Ukraine to stabilize the economy, create conditions for long-term economic growth and increase the competitiveness of the economy. It identifies the need to conduct this study, focuses the attention on the conceptual basis of freefloating exchange rate and «currency board» regimes, and deepen scientific and methodological research base of the studying exchange rate regimes particularly those that would help Ukraine to overcome the crisis. This paper reveals the authors' views on the uses of the new model of exchange rate policy, the success of which depends primarily on the government.
\end{abstract}

Key words: currency regulation, monetary policy, currency exchange rate regime, free-floating exchange rate regime, currency board, inflation.

JEL Classification: E14, E52, G20

Corresponding author:

${ }^{1}$ Department of Finance, National University of «Kyiv-Mohyla Academy».

Email: gluschenkosv@ukma.edu.ua

${ }^{2}$ Department of European Integration, Kyiv National Economic University Vadym Hetman.

Email:sv.tkalenko@gmail.com 


\section{Introduction}

New threats and challenges of the current stage of the world economy development require adapting economies to new geopolitical realities. First of all, these changes relate to international relations, in particular to international monetary relations. Nowadays, Ukraine has consciously chosen the perspective and priority vector of the European integration of its development, which will enable affirmation of Ukraine as an independent state. The economic realities grow faster than any political; thereby the economy of Ukraine in today's conditions (military operations in the East) requires decisive and concerted actions at the political level. The Strategy on Sustainable Development «Ukraine - 2020» was adopted at the beginning of 2015 and the aim of it is the implementation in Ukraine of European standards of living and appear Ukraine on leading position in the world; the strategy envisages implementation of 62 reforms and development program of the state, including reforms of the monetary policy, financial sector and others (Decree of President of Ukraine, 2015). Reforms in the monetary and credit regulations relate primarily to the NBU as a body responsible for the conducting monetary policy and effective levers of influence on the implementation of monetary policy, regulation indicators of monetary market and a number of other measures.

\section{Genesis of exchange rate regimes in Ukraine}

During the development period of independence of Ukraine in Ukrainian practice applied different exchange rate regimes (Table 1 ).

However, over the past twenty years, the devaluation of the hryvnia has been continuing in Ukraine and this indicator reached a level of $147 \%$ for the last two years (2014-2015). This situation demonstrates that the monetary policy and the selected exchange rate regimes by the NBU do not give the expected positive effects for the Ukrainian economy and Ukrainian national currency. The lack of results is also reinforced by the macroeconomic situation in Ukraine, namely economic decline and stagflation, economic helplessness of government regulation and martial law.

Table 1

Exchange Rate Regimes in Ukraine

\begin{tabular}{|l|l|}
\hline \multicolumn{1}{|c|}{ Period } & \multicolumn{1}{|c|}{ Exchange Rate Regime } \\
\hline 1993 & Pure float \\
\hline $1993-1996$ & Fixed peg \\
\hline $1993-1996$ & Fixed peg \\
\hline $1996-2000$ & Fixed band \\
\hline $2000-2008$ & De jure: crawling band. De facto: fixed peg \\
\hline $2008-2014$ & De jure: managed float. De facto: fixed band \\
\hline $2014-$ today & Managed float \\
\hline
\end{tabular}

Therefore, we consider in more detail angular exchange rate regimes, which are suitable for Ukraine and identify their advantages and threats that undermine the expected positive effects of the currency channel influence on the Ukrainian economy. These angular exchange rate regimes, which are appropriate for Ukraine, are:

- free-floating exchange rate regime;

- «currency board» regime.

\section{Free-floating exchange rate regime}

The NBU has identified the main monetary inflation targeting strategy along with free-floating exchange rate regime in current development conditions of the economy of Ukraine (The NBU monetary strategy for 2016-2020). The free-floating exchange rate regime is inherent to the USA, EU, Japan; an inflation targeting with the free-floating exchange rate regime is in countries such as Poland, the Czech Republic, Great Britain, Norway, Canada and others. Thus, experience shows that the inflation targeting with the free-floating exchange rate regime is generally accepted in the countries with developed market relations. In current Ukrainian realities, the transition can be complicated due to underdeveloped markets, unstable fiscal situation, war and so on. However, it is considered that the benefits of such regime will outweigh losses associated with temporary instability in the long term perspective.

The most important benefits include: the intervention in the system of functioning of the foreign exchange market only in case of the exclusivity (this is possible when the IMF provides reliable information that such interventions do not exceed three times over the past 6 months, and the length of it was not more than three days).

At the same time, we should single out a number of threats of the implementation of such regime in Ukraine that explain why in modern format this monetary policy does not bring the expected positive effects in Ukraine. The most important threats include:

Firstly, multicurrency cash flows in the economy (dollarization shocks);

Secondly, disproportions in the structure of the economy, including high import dependency, debt bondage in public and private sectors and economic recession;

Thirdly, a currency exchange rate regimes contradiction between de jure and de facto (such as foreign exchange restrictions on the officially proclaimed free-floating exchange rate).

It can be noted that Ukraine belongs to countries where unofficial dollarization has gained considerable spread, namely an indicator of the dollarization level of the Ukrainian economy, according to the methodology of the IMF, was $29.1 \%$ in 2014. Moreover, it is characteristic for Ukraine both real dollarization (foreign currency uses in operations of purchase and sale within the country) and financial dollarization (foreign currency is a saving instrument). The financial dollarization is confirmed by ratios of foreign currency deposits to total bank deposits, the dollarization level for this indicator is quite high and it was $42,2 \%$ in 2014. Functions of money in the Ukrainian 
economic circulation are fulfilled only partially with hryvnia. It includes the unit of account function, the medium of exchange and payment function and the store of value function (Table 2 ).

The high level of dollarization in the economy (Table 2) causes the presence of a constant demand for foreign exchange. This dependence on foreign exchange of the majority Ukrainian economy entities and the chronic situation for Ukraine concerning exceeding demand for foreign exchange over its supply can become the additional factors that will put pressure on the exchange rate and further enhance its growth trend in favor of foreign exchange, and therefore, provoke instability in the sphere of circulation, consumption, storing, etc. As a result, in the absence of sources for increasing foreign exchange supply or reducing dependence on it (it is the trend of recent years in Ukraine) and aforesaid will threaten the growth of the exchange rate or instability situation, the hryvnia devaluation, inflation and other economic shocks.
Except multicurrency cash flows, disproportions in the domestic economy may also provoke distortions of the currency channel impact on the economy within freefloating exchange rate.

Firstly, the negative balance of export-import trade operations within the balance of payments (Table 3) determines the shortage of currency in the country and consequently provokes additional pressure on the demand for foreign currency and exchange rates fluctuations (not in favor of the national currency) and economic shocks.

Secondly, a situation where the country exports raw materials (products with low added value), and imports final high-tech products (products with high added value), determines the availability of substitution effect in the economy, as foreign exchange earnings from the export of raw materials is lower than foreign exchange costs for procurement (import) of high-tech products. It can also cause the shortage of currency in the country and therefore provoke further pressure on the demand for foreign

Table 2

\section{Execution of functions of money in foreign currency in the Ukrainian economy}

\begin{tabular}{|l|l|l|}
\hline Functions of money & \multicolumn{1}{|c|}{ Private use } & \multicolumn{1}{|c|}{ State use } \\
\hline Unit of account & $\begin{array}{l}\text { - Currency of prices in foreign trade transactions } \\
\text { - Determining prices of the imported goods (electronics, appliances, cars) } \\
\text { - Informal guide of the domestic real estate market and land }\end{array}$ & - Anchor currency \\
\hline $\begin{array}{l}\text { Medium of exchange } \\
\text { and payment }\end{array}$ & $\begin{array}{l}\text { - Currency of payment in foreign trade; } \\
\text { - Internal circulation of other countries (while traveling abroad); } \\
\text { - Foreign exchange transactions } \\
\text { - Crediting }\end{array}$ & $\begin{array}{l}\text { - Currency interventions; } \\
\text { - Payments on foreign loans }\end{array}$ \\
\hline Store of value & $\begin{array}{l}\text { - Private investments } \\
\text { - Deposits of legal entities and individuals }\end{array}$ & - Reserve currency of the NBU \\
\hline
\end{tabular}

Table 3

Dynamics of the Trade Balance of Payments of Ukraine, USD million (NBU, 2016)

\begin{tabular}{|l|c|c|c|c|c|c|c|c|c|}
\hline $\begin{array}{c}\text { Balance } \\
\text { of payments items }\end{array}$ & 2006 & 2007 & 2008 & 2009 & 2010 & 2011 & 2012 & 2013 & 2014 \\
\hline Goods balance & -6046 & -11585 & -17452 & -5343 & -9597 & -18031 & -21846 & -22128 & -7128 \\
\hline Exports of goods & 36174 & 46168 & 63188 & 37134 & 47299 & 62383 & 64427 & 59106 & 50552 \\
\hline Imports of goods & 42220 & 57753 & 80640 & 42477 & 56896 & 80414 & 86273 & 81234 & 57680 \\
\hline
\end{tabular}

Table 4

Dynamics of the Commodity Structure of Ukraine`s Exports, \% (NBU, 2016)

\begin{tabular}{|l|c|c|c|c|c|c|c|c|c|c|}
\hline \multicolumn{1}{|c|}{ Name of Product Groups } & 2005 & 2006 & 2007 & 2008 & 2009 & 2010 & 2011 & 2012 & 2013 & 2014 \\
\hline Total, \% & 100,0 & 100,0 & 100,0 & 100,0 & 100,0 & 100,0 & 100,0 & 100,0 & 100,0 & 100,0 \\
\hline $\begin{array}{l}\text { Food products and raw materials } \\
\text { for their production }\end{array}$ & 13,2 & 13,0 & 13,3 & 16,7 & 25,6 & 21,0 & 20,5 & 27,8 & 28,8 & 33,0 \\
\hline Mineral products & 12,9 & 9,4 & 8,0 & 8,8 & 8,2 & 10,7 & 11,1 & 9,8 & 10,7 & 10,5 \\
\hline $\begin{array}{l}\text { Products of the chemical or allied } \\
\text { industries }\end{array}$ & 10,5 & 11,1 & 10,7 & 10,1 & 8,9 & 8,5 & 9,7 & 9,4 & 8,6 & 7,4 \\
\hline $\begin{array}{l}\text { Wood material and wood } \\
\text { products }\end{array}$ & 2,5 & 2,7 & 2,8 & 2,2 & 3,1 & 3,1 & 3,0 & 2,9 & 3,4 & 3,9 \\
\hline Industrial goods & 1,2 & 1,3 & 1,4 & 1,2 & 1,3 & 1,3 & 1,3 & 1,3 & 1,4 & 1,4 \\
\hline $\begin{array}{l}\text { Ferrous and non-ferrous metals } \\
\text { and articles thereof }\end{array}$ & 42,8 & 45,0 & 44,5 & 43,2 & 33,9 & 36,0 & 35,0 & 28,7 & 28,4 & 29,6 \\
\hline $\begin{array}{l}\text { Machinery, equipment, vehicles } \\
\text { and devices }\end{array}$ & 13,4 & 14,1 & 16,4 & 15,6 & 16,2 & 18,0 & 17,2 & 17,4 & 14,4 & 10,7 \\
\hline Other & 3,4 & 3,4 & 2,9 & 2,2 & 2,7 & 1,3 & 2,2 & 2,8 & 4,2 & 3,6 \\
\hline
\end{tabular}


currency and exchange rates fluctuations (not in favor of the national currency) and economic shocks (NBU, 2016; Babenko V., Shooting J., Mastylo A., 2016).

In 2014, raw materials in the Ukrainian structure of exports amounted to more than 50\% (metals, wood, mineral products, food raw materials), whereas the share of industrial products was equal to $1,4 \%$, and machinery, equipment and vehicles group was $10,7 \%$. In general, this trend was observed in the last 10 years (Table 4 ).

On the other hand, on the contrary, industrial products group accounts $4,5 \%$, and machinery, equipment and vehicles group accounts $18,6 \%$ in the structure of imports (Table 5).

Thirdly, the public external debt and its growing dynamics (or a significant amount) cause the increased demand for foreign currency by the state to repay its debts. There is an existing trend of increasing of the external public debt in Ukraine (Table 6, Figure 1).
If the country is characterized by dollarization, the negative balance of payment and other negative trends in this field, so that there is a temptation for the state as an economic agent to use various exchange restrictions in order to concentrate the currency in its own possession. At the same, the idea of the free exchange rate formation and the free circulation of currency in the country is distorted, and the supply of currency in circulation is more reduced, it may respectively provoke an additional pressure on the demand for foreign currency and currency exchange rates fluctuations (not in favor of the national currency) and economic shocks.

An additional factor that can neutralize effects of influence of the exchange channel at the free-floating exchange rate, is discrepancy between officially (legally) established and actually operating exchange rate formation regimes. This discrepancy can occur, for example, when the country officially defined the

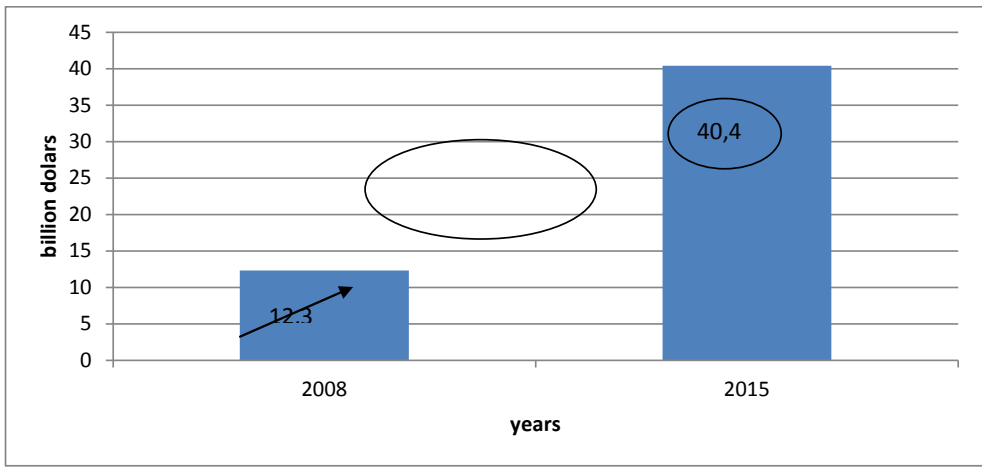

Figure 1. Public Sector External Debt (Government and NBU) for 2008-2015 (at the beginning of the period), USD billion (Pynzenyk Viktor, 2016)

Table 5

Dynamics of the Commodity Structure of Ukraine`s Imports, \% (NBU, 2016)

\begin{tabular}{|l|c|c|c|c|c|c|c|c|c|c|}
\hline \multicolumn{1}{|c|}{ Name of Product Groups } & 2005 & 2006 & 2007 & 2008 & 2009 & 2010 & 2011 & 2012 & 2013 & 2014 \\
\hline Total, \% & 100,0 & 100,0 & 100,0 & 100,0 & 100,0 & 100,0 & 100,0 & 100,0 & 100,0 & 100,0 \\
\hline $\begin{array}{l}\text { Food products and raw materials } \\
\text { for their production }\end{array}$ & 7,7 & 7,3 & 6,8 & 7,7 & 11,6 & 10,1 & 7,9 & 8,7 & 10,1 & 10,4 \\
\hline Mineral products & 28,9 & 26,4 & 25,6 & 27,5 & 33,7 & 33,8 & 33,0 & 30,6 & 26,1 & 26,4 \\
\hline $\begin{array}{l}\text { Products of the chemical or allied } \\
\text { industries }\end{array}$ & 14,8 & 15,3 & 15,2 & 14,4 & 18,8 & 17,8 & 15,6 & 15,2 & 16,1 & 17,9 \\
\hline Wood material and wood products & 3,3 & 3,2 & 3,1 & 2,8 & 3,6 & 3,3 & 2,6 & 2,4 & 2,7 & 2,5 \\
\hline Industrial goods & 4,8 & 4,4 & 3,7 & 4,2 & 4,5 & 5,1 & 3,7 & 4,6 & 4,8 & 4,5 \\
\hline $\begin{array}{l}\text { Ferrous and non-ferrous metals } \\
\text { and articles thereof }\end{array}$ & 7,0 & 7,7 & 8,1 & 7,8 & 6,1 & 7,0 & 6,9 & 5,9 & 5,6 & 5,6 \\
\hline $\begin{array}{l}\text { Machinery, equipment, vehicles } \\
\text { and devices }\end{array}$ & 28,8 & 31,7 & 33,0 & 32,1 & 19,9 & 20,7 & 23,9 & 24,4 & 22,3 & 18,6 \\
\hline Other & 4,8 & 3,9 & 4,6 & 3,6 & 1,9 & 2,2 & 6,6 & 8,1 & 12,4 & 14,0 \\
\hline
\end{tabular}

Table 6

External Debt of Ukraine (at the beginning of the respective year), USD billion

\begin{tabular}{|l|c|c|c|c|c|c|c|c|c|c|}
\hline \multicolumn{1}{|c|}{ Borrowers } & 2006 & 2007 & 2008 & 2009 & 2010 & 2011 & 2012 & 2013 & 2014 & 2015 \\
\hline General Government Sector & 10,51 & 10,92 & 11,88 & 11,96 & 17,81 & 24,98 & 25,87 & 27,33 & 29,92 & 32,88 \\
\hline $\begin{array}{l}\text { Authorities of Monetary } \\
\text { Regulation }\end{array}$ & 1,25 & 0,88 & 0,46 & 4,73 & 6,21 & 7,51 & 7,49 & 4,85 & 1,78 & 2,18 \\
\hline
\end{tabular}


free-floating exchange rates, but in fact bodies of the state regulation (including NBU) use administrative restrictions on foreign exchange markets. As a result of it, the effect of this dual regulatory policy is the inadequacy of the official exchange rate in relation to the real exchange rate, the spread of black markets, currency speculations and etc. It leads to lack of currency and provokes currency exchange rates fluctuations (not in favor of the national currency) and economic shocks.

Moreover, various types of exchange restrictions (including «hidden»), with a shortage of supply of currency, provoke an even greater lack of it, an additional pressure on increasing and formation the exchange rate and increasing the amount of informal («black») exchange markets. It even more enhances exchange fluctuations with a tendency to the growth of foreign exchange rates and determines the need for government intervention in the currency exchange rate formation. In other words, the idea of the free-floating exchange rate is disturbed.

The threat of the leveling effects of the exchange channel at the free-floating exchange rate due to discrepancy between formally (legally) established and actually operating exchange rate formation regimes at the current stage of economic development for Ukraine is confirmed by a number of administrative restrictions on the foreign exchange market of Ukraine in 2014, which, inter alia, include:

- to require the mandatory sale in the interbank market of Ukraine of proceeds in foreign currency as received from abroad including direct sale to the National Bank of Ukraine, at a rate of 75 per cent;

- to limit currency exchange transactions, in particular, it was allowed to carry out operations on sale of foreign currency to one person in one business (working) day in an amount not exceeding the equivalent of $3000 \mathrm{UAH}$ within the same banking institution;

- to restrict transferable currency transactions when on behalf of individuals outside Ukraine permitted to transfer foreign currency at the current exchange non-commercial operations for an amount not exceeding the equivalent of $15000 \mathrm{UAH}$ in one business (working) day;

- to restrict withdrawals of foreign currency deposits up to equivalent of $15000 \mathrm{UAH}$ per day and per customer based on the National Bank of Ukraine official exchange rate (UNIAN, 2014; NBU, 2014; Rudenko, 2015).

After selecting benefits and threats to the current regime in Ukraine, the free-floating exchange rate regime, it is also important to describe benefits and threats of the opposite exchange rate regime, namely the «currency board» regime. Its proponents suggest that it is too early to implement the floating exchange rate regime in Ukraine and the «currency board» regime is the most favorable under conditions of the internal crisis situations in Ukraine's unstable economy. It can provide lower inflation and relatively stable conditions for the foreign trade activity.

\section{4. «Currency board $\gg$ regime: pros and cons}

In April 2014, the US Republican senators Ted Cruz and Marko Rubio expressed the view, that the «currency board» regime can only help the Ukrainian economy. They proposed to the United States Department of the Treasury to collaborate with the IMF in creation of the currency board for Ukraine on its path of European integration, which will not waste financial assistance of the IMF and other organizations (Ukrinform, 2014).

Such an option was offered not only Ukraine, but also Member Countries of the Eastern Caribbean Currency Union (ECCU), on June 6, 2014, the Executive Board of the IMF concluded the 2014 discussion on the common policies of member countries of the ECCU. Limited fiscal space and excessive public debt, financial sector stress, and weak external competiveness continue to hold back economic recovery in these countries (IMF, 2014). Generally, this regime is used to stabilizing the economy and restoring currency convertibility in crisis situations.

The «currency board» regime had been used in 60th years, and then it was revived in 80th, and today it is also used to stabilize the economy. The «currency board» regime essence is that the national currency is tightly tied to the reserve currency; emissions of national banknotes and coins should be fully equipped with a foreign reserve currency and converted into the reserve currency at a fixed rate on the first request. Some flexibility may occur depending on tough requirements, which are set by the «currency board».

The main factor affecting the choice of reserve currency (anchor currency) is a high degree of trade and investment links with the country issuing of the anchor currency. Thus, the country imports confidence in the currency, which is chosen as the anchor currency.

There are the key features of the «currency board» regime: - national currency is maintained at a fixed rate to the anchor currency by law;

- full convertibility of the national currency in foreign is maintained (i.e., the right to exchange the national currency at a fixed rate at any time);

- monetary base should be more than $100 \%$ coverage of gold and currency reserves of the Central Bank;

- changes in the monetary base occur only as a result of changes in international assets;

- the Central Bank cannot be the lender of last resort for commercial banks;

- the Central Bank is not able to conduct their own monetary policy and lend to the government.

The «currency board» regime should contribute to reducing inflation, namely approaching country's inflation rate to anchor currency and monetary stability. To ensure such credibility, three conditions have to be met: sufficient backing of base money (that is, the central bank has to hold sufficient foreign exchange reserves to cover its entire monetary liabilities); a sufficiently restrictive fiscal policy (this in turn requires broad political support - lack of such support could result in a self-fulfilling speculative 
attack); and a reasonably healthy financial system (or the willingness to let weak banks fail). (Anne-Marie Guide, Juha Kahkonen, and Peter Keller, 2000: 5).

The most significant advantages of using the «currency board» regime in Ukraine are the following:

1) to remove from the agenda the issue on money emission;

2) to stop the devaluation of the hryvnia in the future, namely the appreciation of the national currency;

3 ) to reduce inflation and interest rates to a level that is close to an appropriate level of anchor currency country;

4) to improve the Ukrainian investment climate - boost foreign trade and foreign investment flows;

5) to increase the positive balance of payment and increasing the monetary base in circulation;

6) to strengthen Ukraine's ties with the financial system of the country issuing of anchor currency;

7) there is a possibility of repeating the positive experience of the Baltic countries for which the «currency board» regime was the transition to full monetary integration with the European Union;

8) government is no longer credited by the Central Bank, but there is the ability to receive the share premium from the placement of foreign exchange reserves in international markets and to finance the government.

In general, the «currency board» for Ukraine is the option to stabilize the economy in the short period and form the preconditions for further economic growth. This regime was proposed and introduced by the IMF in Bulgaria in 1997 as the mechanism of stabilization, restoring the convertibility of the currency in crisis situations and as a tool for restoring the fiscal discipline; it was a successful example of the monetary stabilization. This exchange rate regime in Bulgaria has contributed to economic growth, the increase of export-import operations, and as a result, to the increase of the competitiveness of the national economy. In Italy, the institutional transformations were performed for the effective use of the «currency board» regime, namely, creating the Italian Foreign Exchange Office for the exchange controls. The «currency board» regime has contributed to effective transition from a centrally planned to market economies in Estonia and Lithuania; Arresting hyperinflation (Argentina, Bulgaria), restoring exchange rate stability after a political and banking crisis (Hong Kong), and providing a stable institutional framework in post-conflict reconstruction (Bosnia (Anne-Marie Guide, Juha Kahkonen, and Peter Keller, 2000: 4, 10). However, it is worth mentioning that the implementation of the «currency board» regime in Argentina also led to the collapse of the financial system in a few years (Sharov, 2014).

The «currency board» regime is not universal remedy, especially for countries with weak banking system and countries, which are prone to asymmetric shocks. Thus, we define a number of implementation threats of this regime in Ukraine, which include the following points:

- availability of dilemma in choosing an anchor currency: the euro or the dollar. On the one hand, Ukraine is oriented towards integration into the EU. On the other hand, the share of the European currency floats at the level of $15.6 \%$ in the calculations, while the share of transactions with the US dollar is about 71\% (NBU, 2015);

- inelasticity of the money supply, and as a result, the limitation of the liquidity in the banking system

- shock for economic entities and population due to the limitation of the money supply at the first phase of the regime;

- lack of economic growth, the increase of the export capacity etc. because of the limitation of the money supply at the first phase of the regime;

- lack of a sufficient amount of reserves in the NBU to ensure $100 \%$ cover of the monetary base. However, the gold and currency reserves ensured $92,65 \%$ cover of the monetary base on January 01, 2016 (official exchange rate of hryvnia against US dollar $=2340,8386 \mathrm{UAH}$ for $100 \mathrm{US}$ dollar, the international reserves $=13300,03$ million US dollars, the monetary base $=336,0$ billion UAH) $(\mathrm{NBU}$ Bulletin, 2015);

- process of the adjustment of high inflation rate in Ukraine and the difference between prices is prolonged for several years. The threat of imported inflation;

- speculative attacks on a currency, which can exhaust the NBU's foreign exchange reserves.

Despite the fact, that in the long term perspective tradeoff between inflation and growth is not positive, failure to conduct permissive financial policy may be an advantage.

\section{Conclusions}

Current conditions, both economic and political, in which Ukraine found itself today, are quite complex and hence it is difficult to choice the applying of further exchange rate regime that would meet current realities and contribute to the economic growth of the economy. The exchange rate regime certainly affects all sectors of the domestic economy, particularly affecting the interests of foreign economic activity entities.

World experience shows that the change of the exchange rate regime requires an effective monetary policy and the availability of relevant macroeconomic conditions in the country. Our analysis on the possibility of using the appropriate exchange rate regimes, namely the free-floating exchange rate and the «currency board» regimes, demonstrated that Ukraine did not overcome the economic crisis and many macroeconomic issues and it has chosen a strategy of transition to floating exchange rate too rapidly. The «currency board» regime should be practically transparent, and have a coherent strategy that would require the government to conduct appropriate monetary and fiscal policies and structural reforms (i.e., government should be disciplined and reformatory). Therefore, we consider that thorough preparation for this transition (it was not in Ukraine) increases the probability that transition of the strategy will be successful. 
The «currency board» regime can justify itself in the current crisis, but also can provide intangible benefits to the economy of Ukraine.

The success of the new model of exchange rate policy is possible under the following conditions:

1. To search own modifications and combinations of exchange rate regimes and instruments of influence on the correlation between currencies.
2. To implement economic reforms of non-monetary nature (demonopolization, deregulation, energy, judicial, banking, institutional and educational reforms, fighting corruption, public and private investment in its own production, etc.).

3. To combine monetary and credit measures with other measures of the state influence on the economy.

\section{References}

Anne-Marie Guide, Juha Kähkönen, and Peter Keller (2000). Pros and Cons of Currency Board Arrangements in the Lead-up to ELF Accession and Participation in the Euro Zone. INF Policy Discussion Paper, January: 26.

Babenko V., Shooting J., Mastylo A. (2016). Primitive economy. As Ukraine has become a raw material appendage. The economic truth, January 9. Retried from: http://www.epravda.com.ua/publications/2016/01/9/575732/

Decree President of Ukraine (2015). Sustainable Development Strategy «Ukraine - 2020». Retried from: http:// zakon4.rada.gov.ua/laws/show/5/2015

IMF (2014) Executive Board Concludes. Discussion on Common Policies of Member Countries of the Eastern Caribbean Currency Union. Press Release No. 14/291 June 19. Retried from: http://www.imf.org/external/np/ $\mathrm{sec} / \mathrm{pr} / 2014 / \mathrm{pr} 14291 . \mathrm{htm}$

NBU (2014). The NBU «On settlement of the situation in the money and foreign exchange markets Ukraine», №758. Retried from: http://zakon0.rada.gov.ua/laws/show/v0758500-14

NBU (2015). The currency structure of settlements with the current account balance. Retried from: http://www. bank.gov.ua/control/uk/publish/article?art_id=65613

NBU (2016). The balance of payments of Ükraine's, Gross external debt of Ukraine's, Foreign trade. - Statistics of the external sector. Retried from: http://bank.gov.ua/control/uk/publish/article?showHidden=1\&art $\mathrm{id}=65613 \&$ cat $\mathrm{id}=44446$

NBU Bulletin (2015). Retried from http://www.bank.gov.ua/control/uk/publish/category?cat_id=57897

Pynzenyk Viktor (2016). The debt of the Ukraine. Retried from: http://www.pynzenyk.com.ua/Analytic/list. php?SECTION_ID=82

Rudenko, V (2015). Foreign exchange restrictions. What has simplified National Bank, December 8. Retried from: http://www.epravda.com.ua/publications/2015/12/8/571340/

Sharov, A. (2014). Next Bretton-Woods: the logic of the international monetary system. Bulletin of the National Bank of Ukraine, August: 19-25

Ukrinform (2014). US senators offer a «tie» the hryvnia to the dollar. Retried from: http://www.ukrinform.ua/ rubric-economics/1651098-amerikanski_senatori_proponuyut_privyazati_grivnyu_do_dolara_1930950.html

UNIAN (2014). NBU has introduced temporary restrictions on the withdrawal of foreign currency deposits. Retried from: http://www.epravda.com.ua/news/2014/02/28/423213/

\section{Светлана ГЛУЩЕНКО, Светлана ТКАЛЕНКО}

\section{УГРОЗЫ И ПРЕИМУЩЕСТВА ВАЛЮТНЫХ РЕЖИМОВ ДЛЯ УКРАИНЫ В УСЛОВИЯХ ЕВРОИНТЕГРАЦИИ}

Аннотация. Целью данной статьи является определение угроз и преимуществ валютных режимов в условиях интеграции Украины в европейское сообщество. Выделение особенностей проявления валютного курсообразования в украинской практике может выступать основой выбора оптимальных валютных режимов для Украины, а это, в свою очередь, позволит снизить инфляцию, внедрить и использовать эффективные инструменты монетарной и фискальной политик, способствовать в дальнейшем экономическому росту и повышению конкурентоспособности страны. Применение режима свободноплавающих валютных курсов и режима «валютного бюро» имеют как положительные эффекты для Украины, так и несут определенные угрозы. Методология. Это исследование основано на синтезе данных по применению валютных режимов в независимой Украине. Рассмотрены наиболее подходящие режимы для Украины на сегодняшний день в условиях европейского вектора развития. Раскрыты особенности применения этих режимов, выделенные преимущества их и самые большие угрозы для отечественной экономики. В данной статье проанализирована динамика товарных операций платежного баланса Украины, динамика товарной структуры экспорта и импорта, внешний долг Украины. Результаты статьи, учитывая опыт стран, которые находились в кризисном состоянии, показывают необходимость применения режима свободноплавающего валютного курса и возможности режима «валютного бюро», несмотря на те угрозы, которые они могут иметь. Мировой 
опыт показывает необходимость проведение структурных реформ, эффективной монетарной политики, фискальной политики, и, дисциплинированности правительства. Тщательная подготовка перехода Украины к режиму «валютного бюро» может себя оправдать в условиях кризиса и дать новый импульс преимуществ украинской экономики. В статье определены условия, при которых возможен успех новой модели валютнокурсовой политики. Практическое значение. В исследование акцентируется внимание на специфике применения режима свободноплавающего валютного курса и режима «валютного бюро» в современных кризисных экономических и политических условиях, и провозглашенной Стратегии устойчивого развития «Украина-2020» в условиях европейского интеграционного вектора развития. Кроме этого выявлены преимущества и угрозы наиболее благоприятных валютных режимов для преодоления экономического кризиса, и соответственно создание предпосылок для дальнейшего экономического роста и повышения конкурентоспособности страны. Эта статья дала возможность выявить условия успеха новой модели валютно-курсовой политики для достижения стабилизации экономики и начала экономического роста. Значение/оригинальность. Несмотря на наличие существующих исследований в области валютного регулирования на сегодняшний день не существует комплексного виденья и единого подхода по применению того или иного валютного режима в Украине, который стабилизирует экономику, создаст предпосылки на перспективу экономического роста отечественной экономики, и повысит ее конкурентоспособность. Это и определяет потребность в проведении данного исследования, акцентирование внимания на концептуальных основах режима свободноплавающего валютного курса и режима «валютного бюро», углубления научнометодологической базы исследования валютных режимов, в том числе тех, которые бы способствовали выходу Украины из кризиса. Эта статьи раскрывает мысли авторов по применению новой модели валютнокурсовой политики, успех которой в первую очередь зависит от правительства. 